\title{
Efficacy and tolerability of BP-Cl in metastatic breast cancer: a Phase II, randomized, double-blind, and placebo-controlled Thai multi-center study
}

This article was published in the following Dove Medical Press journal: Breast Cancer - Targets and Therapy

\author{
Kritiya Butthongkomvong' \\ Nilubol Raunroadroong ${ }^{2}$ \\ Sirikul Sorrarichingchai ${ }^{2}$ \\ Isaraporn Sangsaikae ${ }^{3}$ \\ Vichien Srimuninnimit ${ }^{4}$ \\ Henrik Harling ${ }^{5}$ \\ Stig Larsen ${ }^{6}$ \\ 'Udonthani Cancer Hospital, \\ Udonthani, Thailand; ${ }^{2}$ Lampang \\ Cancer Hospital, Lampang, Thailand; \\ ${ }^{3}$ Ubonratchathani Cancer Hospital, \\ Ubonratchathani, Thailand; ${ }^{4}$ Division \\ of Medical Oncology, Faculty of \\ Medicine, Siriraj Hospital, Mahidol \\ University, Bangkok, Thailand; \\ ${ }^{5}$ Bispebjerg University Hospital, \\ Department of Gastroenterology, \\ Center for Digestive Disease, \\ Copenhagen, Denmark; ${ }^{6}$ Digestive \\ Disease Center, Centre for \\ Epidemiology and Biostatistics, \\ Norwegian University of Life Sciences, \\ Oslo, Norway
}

Correspondence: Stig Larsen Department of Controlled Clinical Trials and Biostatistics, Centre for Epidemiology and Biostatistics, Norwegian University of Life Sciences, Ullevålsveien 72, P.O Box 8 I46 Dep. NO-0033 Oslo, Norway Email stig.larsen@nmbu.no
Aims: The aim of this study was to compare the efficacy and tolerability of BP-C1 vs equallooking placebo in metastatic breast cancer.

Materials and methods: A randomized, double-blind, placebo-controlled multi-center study with a semicross-over design was performed. Sixteen patients received daily intramuscular injection of $0.035 \mathrm{mg} / \mathrm{kg}$ bodyweight of BP-C1 and 15 patients received equal-looking placebo for 32 days. After 32 days, the placebo patients crossed to BP-C1 with the last observation in the placebo period as baseline. The status of receptors including estrogen receptor (ER), progesterone receptor (PtR), and human EGF receptor 2 (HER2) was analyzed prior to inclusion in the study. Thoracoabdominal CT scan was blindly analyzed by the same independent radiologist in accordance with the RECIST criteria 1.1. Toxicity was assessed according to the NCI Bethesda Version 2.0 (CTC-NCI), and the quality of life (QOL) was assessed according to European Organization for the Research and Treatment of Cancer QOL-C30 and QOL-BR23. Results: The sum of target lesion diameters (sum lesions) after 32 days of treatment increased by $8.9 \%(P=0.08)$ in the BP-C1 arm compared to $37.6 \%(P<0.001)$ in placebo patients. Twelve of the 15 placebo patients subsequently had BP-C1 treatment. The increase in sum lesions was $3.5 \%$ in these patients. The sum of CTC-NCI was increased $18.7 \%$ in the BP-C1 arm $(P=0.38)$ compared to $50.9 \%(P=0.04)$ in placebo patients. Four mild/moderate adverse events (AEs) present in BP-C1. Two mild/moderate AEs and one severe AE present in placebo. The QOL benchmarks "breast cancer problems last week", "sexual interest and activity last 4 weeks", and "breast cancer-related pain and discomfort last week" were stable in the BP-C1 arm but deteriorated in placebo patients. The sum lesions increased significantly in $\mathrm{ER}+(P=0.02)$ and $\mathrm{PtR}+(P=0.03)$ but not in HER $2+$. The increase in sum lesions significantly decreased $(P=0.02)$ with an increasing number of negative receptors.

Conclusion: A total of 32 days of BP-C1 treatment inhibited cancer growth and was well tolerated with few and mainly mild AEs. The efficacy of BP-C1 was superior in receptor-negative patients.

ClinicalTrials.gov Identifier: NCT03603197.

Keywords: benzene-polycarboxylic acid complex, BP-C1, low-dose cisplatin, breast cancer, stage IV, hormone receptors, randomized double-blind

\section{Introduction}

A major improvement in the prognosis of breast cancer has occurred during the last few decades, including a median reduction in the breast cancer mortality of $19 \%$ due to novel adjuvant agents and early detection. ${ }^{1,2}$ However, the median overall survival in metastatic breast cancer (MBC) is $\sim 3$ years and the 5-year survival is only $25 \% .{ }^{3,4}$ These figures have not improved substantially, and $\mathrm{MBC}$ is still the leading cause of cancer- 
related deaths in females worldwide. ${ }^{1}$ Findings indicate that improvement in adjuvant treatment of breast cancer induces a negative selection over time to more unfavorable patient characteristics in recent cohorts in those patients who actually develop metastases. This may account for the unchanged outcome of treatment of MBC patients. ${ }^{5}$ While some women with MBC may achieve long-term survival, the therapeutic aim is palliation, balancing treatment efficacy in terms of the delayed progression of the disease and prolonged survival to drug-induced toxicity and AEs because maintaining QOL as long as possible is crucial.

The selection of MBC treatment is guided by patients' choices, age, menopausal and hormone receptor status, disease-related symptoms, burden of metastases, toxicity, comorbid conditions, and prior treatment history. ${ }^{6}$ Additionally, the human EGF receptor 2 (HER2) expression is often taken into account. Surgery, radiation, hormonal therapy, and chemotherapy in addition to immunotherapy and gene therapy are the most common treatments for MBC. ${ }^{7}$ Chemotherapy is considered as the first choice of treatment in women who rapidly develop progressive visceral metastasis or have hormone receptor-negative disease or resistance to endocrine therapy. ${ }^{7}$ However, systemic chemotherapy has less impact with age, severe side effects, and poor response and seldom improves survival substantially. Triple-negative breast cancer (TNBC) is a particular therapeutic challenge. Cytotoxic chemotherapy remains the mainstay of treatment as data from many studies have shown a benefit in the neoadjuvant, adjuvant, and metastatic settings. ${ }^{8-10}$ The TNBC paradox refers to a higher response to chemotherapy in TNBC patients compared to those with other breast cancer types in spite of the general poor prognosis of TNBC. ${ }^{11}$

The role of platinum-based compounds in the treatment of MBC has been extensively studied. Cisplatin and carboplatin are active in previously untreated patients with MBC with mean response rates $50 \%$ and $32 \%$, respectively, but the response rate of platinum monotherapy in pretreated patients declines markedly to $<10 \% .{ }^{12}$ In addition, platinum treatment is hampered by serious systemic toxicities and drug resistance and the pharmacokinetics of most platinum drugs are largely unknown. ${ }^{13}$

In order to develop and provide MBC patients a costeffective treatment with minimal toxicity, a new agent, BP-C1, that is also suitable for the treatment of MBC in the third world, has been introduced. ${ }^{14}$ BP-C1 contains a benzene-poly-carboxylic acid complex with cis-diammineplatinum (II) dichloride, inducing apoptosis in human breast cancer cells. ${ }^{15}$ Previous studies with BP-C1 in the treatment of MBC patients have shown that tumor growth decreased without causing extra toxicity, ${ }^{14,16}$ although mainly manageable mild-to-moderate transient side effects may occur.

The primary aim of the present study was to compare the palliative efficacy and tolerability of BP-C1 with a placebo during 32 days of continuous treatment of patients suffering from pre-treated MBC. The secondary aim was to analyze if the efficacy of BP-C1 was related to the receptor status of the patients in a subset analysis.

\section{Materials and methods}

The Ethical Committee of the Institute for Development of Human Research in Thailand approved the study on June 17, 2013. All patients gave their written informed consent to participate before being included in the study. The author and the co-authors have completed the conflict of interest form and ensured that no such conflict exists.

The study population consisted of female patients between the age of 18 and 80 years, suffering from histologically verified $\mathrm{MBC}$ with measurable metastases, who had previously undergone at least two lines of chemotherapy and had an expected survival time of at least 3 months.

Patients with bilirubin $>34 \mu \mathrm{mol} / \mathrm{L}$ or Alain aminotransferase (ALAT) more than three times the upper limit of normal range, serum creatinine $>120 \mu \mathrm{mol} / \mathrm{L}, \mathrm{Hgb}<6.0 \mathrm{mmol} / \mathrm{L}$, platelet count $<100,000 / \mathrm{mm}^{3}$, or leucocytes $<3 \times 10^{9} / \mathrm{L}$ or who had an abnormal coagulation capacity were excluded from the study. Additionally, patients with verified brain metastasis, synchronous cancer, clinically significant abnormal ECG, or a Karnofsky score of $<60 \%$ were excluded. Finally, patients under systemic treatment with corticosteroids or other immunosuppressive drugs the previous 21 days and patients with uncontrolled bacterial, viral, fungal, or parasite infection were excluded from the study population.

The study sample consisted of 31 patients from 4 of the 11 territorial Thai cancer hospitals (Table 1). By block randomization, 16 patients were allocated to $\mathrm{BP}-\mathrm{C} 1$ and 15 patients were allocated to an equal-looking placebo treatment for 32 days. Twelve of the 15 patients allocated to placebo had BP-C1 after finalizing the placebo period. Due to rapid disease progression, the remaining three patients were withdrawn from the study and had terminal care.

The general condition was "good" or "very good" in most of the patients at baseline. Two patients in the BP-C1 group and three patients in the placebo group were classified as "fair". The two groups were comparable with regard to all the initially recorded baseline characteristics, previous cancer 
Table I Baseline characteristics and previous cancer treatments

\begin{tabular}{|c|c|c|c|}
\hline \multirow{2}{*}{\multicolumn{2}{|c|}{ Factor specifications }} & \multicolumn{2}{|c|}{$\begin{array}{l}\text { Controlled clinical } \\
\text { study }\end{array}$} \\
\hline & & $\begin{array}{l}\text { BP-CI } \\
(N=16)\end{array}$ & $\begin{array}{l}\text { Placebo } \\
(N=15)\end{array}$ \\
\hline $\begin{array}{l}\text { Demographic } \\
\text { factors and vital } \\
\text { signs }\end{array}$ & $\begin{array}{l}\text { Age (years) } \\
\text { Duration of } \\
\text { disease (years) } \\
\text { BMI }\left(\mathrm{kg} / \mathrm{m}^{2}\right) \\
\\
\text { Systolic blood } \\
\text { pressure (mmHg) } \\
\text { Diastolic blood } \\
\text { pressure }(\mathrm{mmHg}) \\
\text { Heart rate } \\
\text { (beats } / \mathrm{min}) \\
\text { Respiratory rate } \\
\text { (breath/min) }\end{array}$ & $\begin{array}{l}52.1(7.2) \\
35.6-64.2 \\
4.9(3.2) \\
1.5-11.2 \\
23.0(3.0) \\
17.1-29.3 \\
117(16) \\
92-140 \\
76(9) \\
64-93 \\
91(12) \\
76-112 \\
19.9(1.1) \\
18.0-22.0\end{array}$ & $\begin{array}{l}56.4(10.1) \\
35.6-74.3 \\
4.03(2.2) \\
1.4-8.8 \\
21.9(4.8) \\
13.3-30.9 \\
121(14) \\
95-151 \\
75(12) \\
54-94 \\
88(13) \\
62-112 \\
20.5(0.9) \\
20.0-22.0\end{array}$ \\
\hline $\begin{array}{l}\text { Previous cancer } \\
\text { treatment }\end{array}$ & $\begin{array}{l}\text { Surgery } \\
\text { Hormone } \\
\text { therapy } \\
\text { Antibody therapy } \\
\text { Radiotherapy } \\
\text { Others }\end{array}$ & $\begin{array}{l}14 \\
8 \\
0 \\
13 \\
0\end{array}$ & $\begin{array}{l}14 \\
8 \\
0 \\
13 \\
0\end{array}$ \\
\hline
\end{tabular}

Notes: Assumed continuously distributed factors are expressed by mean value, $\mathrm{StD}$ in brackets, and total range. The discrete factors are expressed in the number of patients.

Abbreviation: BMI, body mass index; StD, standard deviation.

treatments, and clinical findings. The study was carried out between June 2014 and August 2016.

\section{Design and randomization}

The first part of the study was performed as a randomized, double-blind, and placebo-controlled multi-center trial with a stratified semicross-over design. ${ }^{17}$ The stratification factors were age and hospital site. The three age strata were as follows: $\leq 45,46-60$, and $\geq 60$ years. The patients within each stratum were allocated $1: 1$ to $\mathrm{BP}-\mathrm{C} 1$ or an equal-looking placebo by block randomization with random block size between four and eight. ${ }^{18} \mathrm{~A}$ total of $1 \mathrm{~mL}$ of the placebo consisted of caramel color E150a (12.5 mg) diluted in an isotonic solution. The randomization code was broken after 32 days, and the patients allocated to placebo then had BP-C1 for an additional 32 days of treatment. The baseline for this group after reallocation was the last observation before changing to $\mathrm{BP}-\mathrm{C} 1$. The patients allocated to $\mathrm{BP}-\mathrm{C} 1$ by randomization together with the patients later changed to $\mathrm{BP}-\mathrm{C} 1$ form the joint BP-C1 group. The second part of the study was an openlabel multi-center trial in this joint BP-C1 group.
Main variables were percentage change in the sum of diameters of up to five of the largest target lesions (sum lesions) measured by CT using the RECIST criteria 1.1. After 32 days of treatment, the patients were classified according to the RECIST criteria as complete responder (CR), partial responder (PR), stable disease (SD), or progressive disease (PD). The Toxicity Criteria NCI Bethesda (CTC-NCI) Version 2.0 was used for the measurement of the tolerability. The sum of CTC score and the maximum score (max CTC) were used as variables. The QOL was recorded by using QLQ-C30 and QLQ-BR23 from the European Organization for the Research and Treatment of Cancer. The QOL variables were developed from the QOL questionnaires, as recommended. The sum of scores within each of the three parts in the two questionnaires QLQ-C30 and QLQ-BR23 resulted in three variables. The three sum of scores obtained from QOL-C30 are questions C1-C5 "physical activity problems", questions C6-C28 "discomfort last week", and questions C29-C30 "health and life quality". From QOL-BR23, the developed variables were questions BR1-BR13 "problems related to the breast cancer treatment last week", questions BR14-BR16 "sexual interest and activity last 4 weeks", and questions BR17-BR 23 "breast cancer-related pain and discomfort last week".

\section{Study procedures}

Patients fulfilling the criteria for participation and having given their written consent to participate were entered into a screening phase of maximum 21 days. Laboratory screening was performed in order to ensure the exclusion criteria, and samples for the receptor status were taken. Estrogen receptor (ER), progesterone receptor (PtR), and HER2 were recorded as positive $(+)$ or negative $(-)$. It is ER-alfa and PR A-form given. During the screening phase, thoracoabdominal CT scans were performed, and in case of suspected bone or brain metastases, an MRI was taken. Additionally, CTC-NCI, QLQ-C30, and QLQ-BR23 were recorded by the patients. Each patient was given an identification number, hiding the treatment randomization code. The trial injections started on Day 1, and the patients received one daily Intramuscularly (IM) injection during a treatment period of 32 days. The daily BP-C1 or equal-looking placebo dose was $0.035 \mathrm{mg} /$ $\mathrm{kg}$ bodyweight (BW) or $0.07 \mathrm{~mL} / \mathrm{kg} \mathrm{BW}$. BP-C1 was sent from the hospital to the local medical center, and a nurse gave the patients the injections in either the clinic or the patient's home. Clinical and laboratory examinations took place after 16 and 32 days of treatment designated as Day 16 (16 \pm 2 days) and Day 32 (33 \pm 1 days), respectively. Blood samples for 
laboratory examination, CTC-NCI, adverse events (AEs), and QLQ were performed and recorded. Thoracoabdominal CTs were performed at Day 32, and the patients were classified as CR, PR, SD, or PD in accordance with the RECIST procedure. At the end of the 32-day treatment period, the randomization code was broken.

The patients allocated to placebo were crossed-over to BP-C1 for an additional 32 days of treatment and were followed up as previously described for the first treatment period. New CTs of the chest and abdomen and blood samples for laboratory examination were taken, and CTC-NCIs, AEs, and QLQs were performed and recorded.

\section{Statistical analysis}

The main variables in the study are percentage change from baseline to final measurement. Distribution analysis was performed by using the Shapiro-Wilk test, ${ }^{19}$ Daniel half-normal plot, ${ }^{20}$ and trace analysis. ${ }^{21}$ All continuously distributed main variables were unimodal and symmetrically distributed, reported as mean values with StD in brackets and 95\% CIs, and calculated in accordance with the Student's procedure. ${ }^{22}$ Discrete and categorical variables are reported in contingency tables. ${ }^{23}$ Changes in discrete variables are given in switch tables. In case of missing observation, the procedure "last observation carried forward" was used. ${ }^{24,25}$

All comparisons between study arms and groups were performed two tailed, and differences considered significant for $P$-values $\leq 5 \%$. Analysis of covariance was performed for the comparison of groups with regard to the continuously distributed variables with the initial observation and hospital site as covariate. ${ }^{26}$ A contingency table analysis was used for a comparison of the groups with regard to discrete and categorical variables. $^{23}$

\section{Ethics approval}

Institute for Development of Human Research Protection (IHRP), Thailand, June 17, 2013, approved this study.

\section{Results}

\section{Tumor growth and RECIST}

The sum lesions increased from $53.6 \mathrm{~mm}$ (95\% CI: $33.5-$ $73.8)$ to $55.5 \mathrm{~mm}$ (95\% CI: $35.4-75.6)$ in the BP-C1 group and from $60.6 \mathrm{~mm}(95 \% \mathrm{CI}: 35.1-86.1)$ to $79.1 \mathrm{~mm}(95 \% \mathrm{CI}$ : 46.5-111.7) in the placebo group during the 32 days of treatment (Figure 1). This represents an increase of $8.9 \%(95 \% \mathrm{CI}$ : $-0.1-17.9)$ and $37.6 \%$ (95\% CI: 24.3-50.9) in the BP-C1 and the placebo groups, respectively. The increase in the placebo group was significant $(P<0.001)$ but not in the BP-C1 group.
The difference between the groups in percentage increase in sum lesions was significantly in favor of BP-C1 $(P<0.01)$. Twelve of the 15 patients in the placebo group were crossedover to 32 days of BP-C1 treatment (Figure 1). The sum lesions in this group increased by $35.2 \%$ during the placebo period and increased from $70.9 \mathrm{~mm}$ (95\% CI: 35.7-106.2) to $71.6 \mathrm{~mm}(95 \% \mathrm{CI}: 35.9-107.3)$, representing an increase of $3.5 \%$ after switching to BP-C1.

A significant difference $(P<0.01)$ was detected in favor of BP-C1 regarding the treatment classification in accordance with the RECIST criteria (Table 2). Thus, $81.3 \%$ were classified as SD in the BP-C1 group and 33.3\% were classified as $\mathrm{SD}$ in the placebo group. After switching from placebo to BP-C1, 91.7\% were classified as SD (Table 2). In the joint

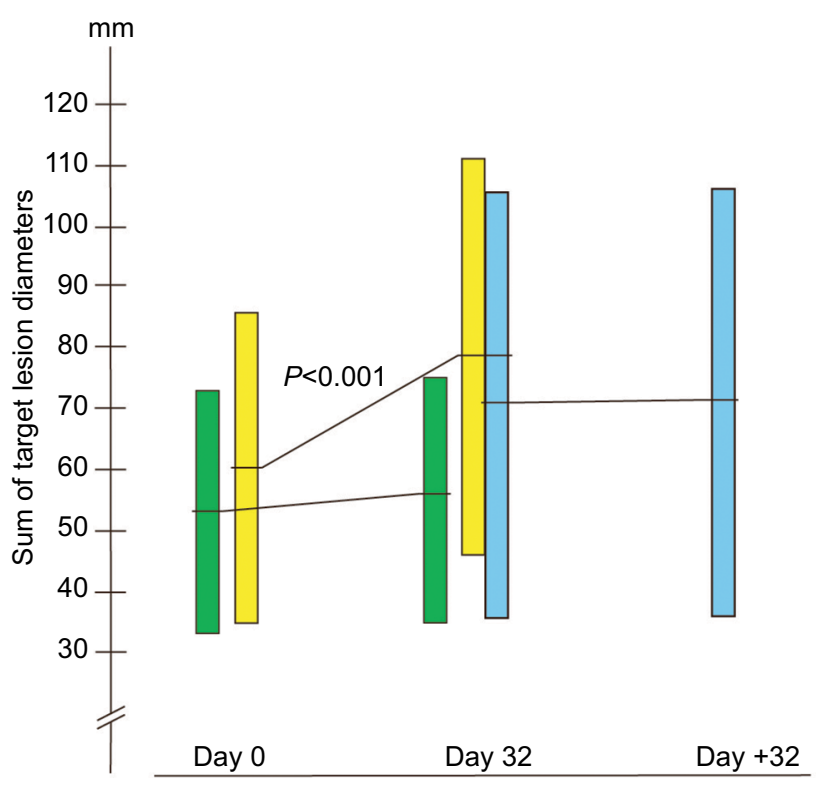

Figure I The development in sum of the largest diameters of target lesions in millimeter.

Notes: The results are expressed by mean values with $95 \% \mathrm{Cls}$ illustrated by columns. The horizontal line crossing the columns shows the mean values. The green column shows $\mathrm{BP}-\mathrm{Cl}$, and the yellow column shows placebo. The blue column shows the development in the 12 patients after switching from placebo to $\mathrm{BP}-\mathrm{Cl}$.

Table 2 Treatment response after 32-day of treatment with BP$\mathrm{Cl}$ and placebo

\begin{tabular}{|l|l|l|l|}
\hline \multirow{2}{*}{ Treatment group } & \multicolumn{2}{|l|}{ Day 32 of treatment } & \multirow{2}{*}{ Total } \\
\cline { 2 - 4 } & PD & SD & \\
\hline Randomized to BP-CI & 3 & $13(81.3 \%[54.3-96.0])$ & 16 \\
\hline Randomized to placebo & 10 & $5(33.3 \%[\mathrm{II} .8-61.6])$ & 15 \\
\hline $\begin{array}{l}\text { Placebo group crossed } \\
\text { over to BP-CI }\end{array}$ & $\mathrm{I}$ & $\mathrm{II}(9 \mathrm{I} .7 \%[6 \mathrm{I} .5-99.8])$ & $\mathrm{I} 2$ \\
\hline Joint BP-CI group & 4 & $24(85.7 \%[67.3-96.0])$ & 28 \\
\hline
\end{tabular}

Note: The results expressed as observed numbers with percent responder and $95 \% \mathrm{Cl}$.

Abbreviations: PD, progressive disease; SD, stable disease. 
BP-C1 group, 24 of the 28 patients were classified as SD, representing $85.7 \%$.

\section{Tolerability}

The sum of CTC-NCI score in the BP-C1 group declined slightly during the first 16 days, but overall, it increased nonsignificantly, with $18.7 \%$ from screening to Day 32 (Figure 2). In the placebo group, the sum of CTC-NCI score increased continuously and significantly $(P=0.04)$ with $50.9 \%$ during the similar 32 days of treatment. The results were in favor of BP-C1, but the difference was not significant $(P=0.22)$. The development of the sum CTC-NCI score in the placebo patients crossed to BP-C1 followed the same pattern as obtained in the patients randomized to BP-C1 and ended with a nonsignificant increase of $45.2 \%$ from baseline to Day 32. The sum of CTC-NCI score in the joint BP-C1 group increased nonsignificantly with $29.2 \%$ during the treatment.

\section{Adverse events}

A total of 310 mild-to-moderate AEs and 10 severe AEs were reported in the BP-C1 group compared to 318 mildto-moderate AEs and 29 severe AEs in the placebo group. Four mild-to-moderate AEs were classified as "possible" or "probably" related to the BP-C1 treatment. Two of these were gastrointestinal disorders and two related to the injection site. In the placebo group, two mild-to-moderate AEs and one severe AE were classified as related to the treatment. Of these, one was a gastrointestinal disorder,

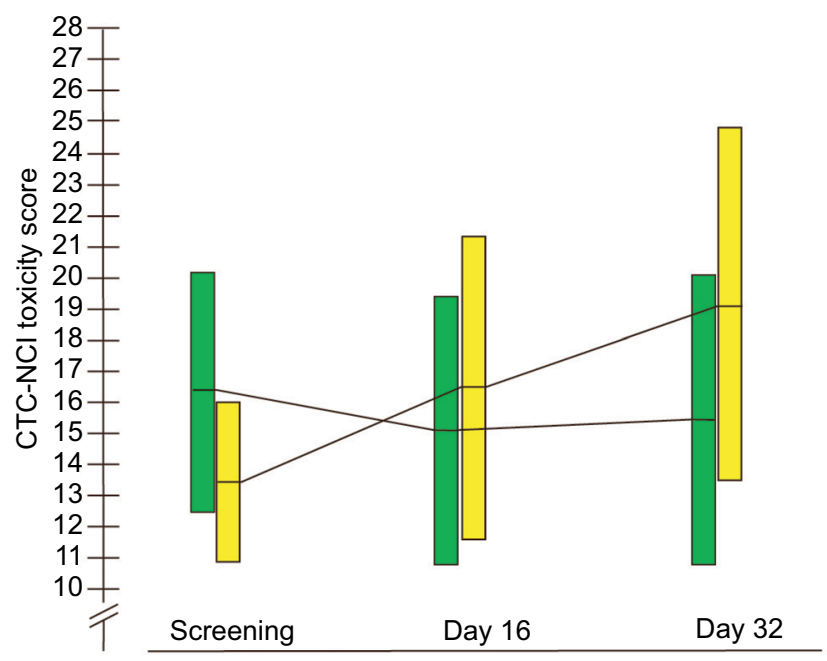

Figure 2 The development in sum of CTC-NCI toxicity score from screening to Days 16 and 32 in the BP-Cl group and the placebo group.

Notes: The results are expressed by mean values with $95 \% \mathrm{Cls}$ illustrated by columns. The horizontal line crossing the columns shows the mean values. The green column shows $\mathrm{BP}-\mathrm{Cl}$, and the yellow column shows placebo. one was injection site related, and one was severe due to an increase in ALT. During the study, six serious AEs occurred in three patients; all randomized to placebo but were not classified as related to treatment. Additionally, one patient died after 31 placebo injections, before the planned change to BP-C1 treatment.

\section{QOL questionnaires}

"Physical activity problems last week" increased nonsignificantly during the 32 days of treatment in both groups. A similar pattern was observed for "discomfort last week". This was unchanged the first 16 days but slightly increased in both groups at Day 32. The "health and life quality" score did not change significantly either within or between the treatment groups. The evolution of these three variables in the 12 placebo patients changed to BP-C1 treatment after 32 days showed the same pattern as recorded in the BP-C1 group.

"Breast cancer problems last week" and "sexual interest and activity last 4 weeks" remained unchanged in both groups during 32 days treatment (Table 3). "Breast cancer-related pain and discomfort last week" was unchanged in the BP-C1 group but increased in the placebo group from screening to Day 32.

"Breast cancer treatment problems last week" and "breast cancer-related pain and discomfort last week" declined after changing from placebo to 32 days of BP-C1 treatment. "Breast cancer-related pain and discomfort" declined significantly $(P \leq 0.05)$ and "sexual interest and activity last 4 weeks" increased nonsignificantly.

In the joint BP-C1 group, both "breast cancer treatment problems last week" and "sexual interest and activity last 4 weeks" were nearly unchanged from the start of BP-C1 to Day 32. The "breast cancer-related pain and discomfort last week" score declined nonsignificantly by $2.3 \%$ during the same treatment.

\section{Tumor growth related to receptor status}

The ratio of negative/positive ER was 13/15, that of PtR was $15 / 13$, and that of HER2 was $15 / 13$ in the 28 patients of the joint BP-C1 treated group (Table 4). The sum of target lesion diameters increased significantly in the ER-positive group $(P=0.02)$, whereas a nonsignificant reduction $(P=0.08)$ was observed in the group with negative ER. The percentage change in the sum lesions was in favor of negative ER $(P=0.12)$. The sum of diameter in the group with positive PtR increased significantly $(P=0.03)$, whereas the negative PtRs declined nonsignificantly. The percentage change in sum lesions was significantly in favor of negative $\operatorname{PtR}(P=0.02)$. No significant differences were observed between positive 
Table 3 Comparison between groups and development within groups with regard to the sum of scores within each of the three parts in questionnaires QLQ-BR23Cls

\begin{tabular}{|c|c|c|c|c|c|}
\hline Variables & Treatments & Screening & $\begin{array}{l}\text { Day } 16 \text { of } \\
\text { treatment }\end{array}$ & $\begin{array}{l}\text { Day } 32 \text { of } \\
\text { treatment }\end{array}$ & $\begin{array}{l}\text { Increase } \\
\text { (day 32-screening) }\end{array}$ \\
\hline \multirow[t]{2}{*}{$\begin{array}{l}\text { Breast cancer treatment } \\
\text { problems last week }\end{array}$} & $\mathrm{BP}-\mathrm{Cl}(\mathrm{N}=16)$ & $\begin{array}{l}16 . \mid(3.6) \\
|4 .|-18.0\end{array}$ & $\begin{array}{l}14.3(4.6) \\
\mid 1.8-16.8\end{array}$ & $\begin{array}{l}16.5(3.2) \\
\mid 4.8-18.2\end{array}$ & $\begin{array}{l}0.4(2.8) \\
-1.0 \text { to } 1.9\end{array}$ \\
\hline & Placebo $(\mathrm{N}=15)$ & $\begin{array}{l}15.3(2.3) \\
14.0-16.5 \\
\end{array}$ & $\begin{array}{l}15.3(2.4) \\
13.9-16.6 \\
\end{array}$ & $\begin{array}{l}15.3(2.5) \\
14.0-16.7 \\
\end{array}$ & $\begin{array}{l}0.1(3.2) \\
-1.7 \text { to } 1.8\end{array}$ \\
\hline \multirow[t]{2}{*}{$\begin{array}{l}\text { Sexual interest and } \\
\text { activity last } 4 \text { weeks }\end{array}$} & BP-CI $(\mathrm{N}=16)$ & $\begin{array}{l}3.1(1.8) \\
2.2-4.1\end{array}$ & $\begin{array}{l}2.8(1.8) \\
1.9-3.8\end{array}$ & $\begin{array}{l}2.8(1.6) \\
1.9-3.6\end{array}$ & $\begin{array}{l}-0.4(1.5) \\
-1.2 \text { to } 0.4\end{array}$ \\
\hline & Placebo $(\mathrm{N}=15)$ & $\begin{array}{l}3.4(2.1) \\
2.3-4.5\end{array}$ & $\begin{array}{l}2.7(1.6) \\
1.9-3.6\end{array}$ & $\begin{array}{l}2.2(0.6) \\
1.9-2.5\end{array}$ & $\begin{array}{l}-1.2(2.1) \\
-2.4 \text { to }-0.1\end{array}$ \\
\hline \multirow[t]{2}{*}{$\begin{array}{l}\text { Breast cancer-related pain } \\
\text { and discomfort last week }\end{array}$} & $\mathrm{BP}-\mathrm{Cl}(\mathrm{N}=16)$ & $\begin{array}{l}11.1(4.1) \\
8.9-13.3 \\
\end{array}$ & $\begin{array}{l}10.0(4.0) \\
7.4-12.6 \\
\end{array}$ & $\begin{array}{l}11.3(4.6) \\
8.9-13.7 \\
\end{array}$ & $\begin{array}{l}0.2(2.1) \\
-0.9 \text { to } 1.3\end{array}$ \\
\hline & Placebo $(\mathrm{N}=15)$ & $\begin{array}{l}9.6(1.9) \\
8.5-10.7\end{array}$ & $\begin{array}{l}10.0(3.0) \\
8.3-11.7\end{array}$ & $\begin{array}{l}10.5(4.1) \\
8.3-12.8\end{array}$ & $\begin{array}{l}0.9(2.9) \\
-0.7 \text { to } 2.5\end{array}$ \\
\hline
\end{tabular}

Note: The results expressed as mean values with $95 \% \mathrm{Cls}$ and StD in brackets.

Abbreviation: StD, standard deviation.

Table 4 "Negative" and "positive" ER, PR, and HER2 comparison with regard the development in the sum of target diameter lesions

\begin{tabular}{|c|c|c|c|c|c|}
\hline \multirow[t]{2}{*}{ Receptors } & \multirow[t]{2}{*}{ Classification } & \multicolumn{3}{|c|}{ Sum lesion diameter } & \multirow[t]{2}{*}{$P$-value } \\
\hline & & Baseline & Day 32 & $\begin{array}{l}\text { \% (Day } 32 \\
\text { to baseline) }\end{array}$ & \\
\hline \multirow[t]{4}{*}{ ER } & Negative $(n=13)$ & $56.5(38.9)$ & $54.9(39.6)$ & $-0.4(20.9)$ & \multirow[t]{4}{*}{0.12} \\
\hline & & $32.9-80.0$ & $31.0-78.9$ & -12.9 to 12.3 & \\
\hline & Positive $(n=15)$ & $58.2(54.7)$ & $61.3(54.3)$ & II.4 (I8.3) & \\
\hline & & $27.9-88,5$ & $31.2-91.4$ & $1.3-21.6$ & \\
\hline \multirow[t]{4}{*}{ PtR } & Negative $(n=15)$ & $66.3(43.1)$ & $65.6(46.3)$ & $-2.0(16.2)$ & \multirow[t]{4}{*}{0.02} \\
\hline & & $42.4-90.1$ & $39.9-91.3$ & -11.0 to 6.9 & \\
\hline & Positive $(n=13)$ & $42.2(5 \mid .3)$ & $49.9(48.9)$ & I5.2(20.7) & \\
\hline & & $16.1-78.2$ & $20.4-79.4$ & $2.6-27.7$ & \\
\hline \multirow[t]{4}{*}{ HER2 } & Negative $(n=15)$ & $60.8(52.5)$ & $62.4(53.4)$ & $4.3(13.0)$ & \multirow[t]{4}{*}{0.64} \\
\hline & & $31.7-89.9$ & $32.5-91.7$ & -2.9 to $1 \mathrm{I} .4$ & \\
\hline & Positive $(n=13)$ & $53.5(42.0)$ & $53.9(40.8)$ & $7.9(26.5)$ & \\
\hline & & $28.1-78.8$ & $29.2-78.6$ & -8.1 to 24.0 & \\
\hline
\end{tabular}

Note: The results expressed by mean values, StD in brackets, and $95 \% \mathrm{Cls}$.

Abbreviations: ER, estrogen receptor; HER2, human EGF receptor 2; PtR, progesterone receptor; StD, standard deviation.

and negative HER2 patients. The increase in sum lesions was significantly reduced $(P=0.03)$ with increasing number of negative receptors (Table 5). In this pooled group of $0-1$ negative receptors, a significant increase of $13.6 \%(95 \% \mathrm{CI}$ : $2.7 \%-24.5 \%)$ in sum of diameters was recorded $(P=0.03)$. The group with 2-3 negative receptors showed a reduction in the sum lesions of $2.8 \%$ (95\% CI: $-13.2-7.6 .2)$. The percentage change in sum lesions was significantly in favor of double- or triple-negative receptors $(P=0.03)$.

\section{Discussion}

This study has demonstrated that $86 \%$ of pretreated women with MBC from rural Thailand obtained SD according to the
RECIST criteria ${ }^{27}$ after one daily IM injection for 32 days of the novel platinum compound BP-C1. The efficacy of BP-C1 increased parallel to the number of negative ER, PtR, and HER2 receptor, and both the QOL and toxicity were more favorable compared to the placebo. Only few and mild-tomoderate AEs were registered as probably related to BP-C1 treatment.

The first clinically approved and best-studied platinum compound was cisplatin, ${ }^{28}$ and the second approved was carboplatin. ${ }^{29}$ Numerous studies of platinum compounds' synthesis and efficacy have been conducted, but insufficient selectivity for malignant cells, severe side effects, and drug resistance are still characteristic features of these drugs. $.^{30,31} \mathrm{BP}-\mathrm{C} 1$ was 
Table 5 Comparison of number of negative receptors with regard the development in the sum of target diameter lesionsCls

\begin{tabular}{|c|c|c|c|c|}
\hline \multirow{2}{*}{$\begin{array}{l}\text { Number of } \\
\text { negative receptors }\end{array}$} & \multicolumn{3}{|c|}{ Sum lesion diameter } & \multirow[t]{2}{*}{$P$-value } \\
\hline & Baseline & Day 32 & $\begin{array}{l}\% \text { (Day } 32 \text { to } \\
\text { baseline) }\end{array}$ & \\
\hline $\begin{array}{l}0 \text { negative } \\
\text { receptors }(n=3)\end{array}$ & $\begin{array}{l}34.3(31.8) \\
-44.7 \text { to I I } 3.4\end{array}$ & $\begin{array}{l}40.7(31.4) \\
-37.3 \text { to } 118.6\end{array}$ & $\begin{array}{l}29.3(32.5) \\
-51.5 \text { to } 110.2\end{array}$ & \multirow{4}{*}{0.03} \\
\hline $\begin{array}{l}\text { I negative } \\
\text { receptor }(n=\mid 2)\end{array}$ & $\begin{array}{l}53.8(53.9) \\
19.6 \text { to } 88.1\end{array}$ & $\begin{array}{l}55.8(52.3) \\
22.6 \text { to } 89.0\end{array}$ & $\begin{array}{l}9.7(14.7) \\
0.3 \text { to } 19.0\end{array}$ & \\
\hline $\begin{array}{l}2 \text { negative } \\
\text { receptors }(\mathrm{n}=8)\end{array}$ & $\begin{array}{l}72.5(52.4) \\
28.7 \text { to } 116.3\end{array}$ & $\begin{array}{l}70.4(55.0) \\
24.4 \text { to } 116.3\end{array}$ & $\begin{array}{l}-3.0(20.3) \\
-20.0 \text { to } \mid 4.0\end{array}$ & \\
\hline $\begin{array}{l}3 \text { negative } \\
\text { receptors }(n=5)\end{array}$ & $\begin{array}{l}55.6(28.6) \\
20.0 \text { to } 91.2\end{array}$ & $\begin{array}{l}55.6(35.5) \\
11.5 \text { to } 99.7\end{array}$ & $\begin{array}{l}-2.6(13.0) \\
-18.8 \text { to } 13.5\end{array}$ & \\
\hline $\begin{array}{l}0 \text { or I negative } \\
\text { receptor }(n=15)\end{array}$ & $\begin{array}{l}49.0(50.0) \\
22.3 \text { to } 77.6\end{array}$ & $\begin{array}{l}52.8(48.2) \\
26.1 \text { to } 79.5\end{array}$ & $\begin{array}{l}13.6(19.7) \\
2.7 \text { to } 24.5\end{array}$ & \multirow[b]{2}{*}{0.03} \\
\hline $\begin{array}{l}2 \text { or } 3 \text { negative } \\
\text { receptors }(n=13)\end{array}$ & $\begin{array}{l}66.0(44.1) \\
39.3 \text { to } 92.7\end{array}$ & $\begin{array}{l}64.7(47.3) \\
36.1 \text { to } 93.3\end{array}$ & $\begin{array}{l}-2.8(17.3) \\
-13.3 \text { to } 7.6\end{array}$ & \\
\hline
\end{tabular}

Note: The results expressed by mean values, StD in brackets, and $95 \% \mathrm{Cls}$. Abbreviation: StD, standard deviation.

developed for the treatment of $\mathrm{MBC}$ and pancreatic cancer. The safety and efficacy of cisplatin, carboplatin, and BP-C1 have been compared in mice with Ehrlich tumors. ${ }^{32}$ The three drugs stimulated apoptosis in tumor tissue, and the specific activity of BP-C1 was similar to that of an equimolar dose of carboplatin but with lower toxicity. The specific activity was lower compared to cisplatin, but significantly superior in terms of toxicity, accumulation of bound platinum, and duration of antitumor effect. The pharmacokinetic profile in dogs follows a two-compartment model with rapid absorption, short distribution, a slow elimination phase, and an overall elimination half-life of 125 hours. ${ }^{33}$ BP-C1 is a category 2 anticancer drug ${ }^{34}$ and can be safely administrated continuously for 32 days. ${ }^{14}$ The daily maximum tolerated dose (MTD) is $>0.035 \mathrm{mg} / \mathrm{kg}$, and the minimum efficient dose is estimated to $0.03 \mathrm{mg} / \mathrm{kg}$. Based on the MTD, BP-C1 is therefore injected IM once daily in a dose of $1.12 \mathrm{mg} / \mathrm{kg} / 32$ or $0.035 \mathrm{mg} / \mathrm{kg}$. In addition to being cytostatic, BP-C1 has immunomodulatory properties. ${ }^{35}$ Thus, activation of monocytes leads to two major effects - production of cytokines that are able to increase antitumor activity of lymphocytes, and monocytes will acquire the ability to inhibit tumor cell growth. In addition, BP-C1 directly effects lymphocytes, exemplified by the induction of IL-25. Finally, BP-C1 has a favorable toxicity profile ${ }^{14,16}$ and exerts a positive effect on hematological and biochemical imbalances in patients with MBC. ${ }^{36}$

The present study confirmed our previously published results from two international multicentre studies in pretreated MBC patients. ${ }^{14,16}$ Thus, short-term BP-C1 treatment reduced tumor growth, was well tolerated, improved the QOL, and had few and mainly mild AEs. Most of the patients in our study were recruited from the countryside or small county cities. Such patient populations are closely interconnected to relatives, neighbors, and the neighborhood. When moving such patients to the hospital far away from the neighborhood, their QOL is significantly reduced. A well-equipped and clean hospital with good clinical support and optimal medical treatment is not sufficient to make up for this loss. A major advantage of BP-C1 is therefore that it can be administered in the home of the patient and, at the same time, they can avoid meeting and receiving treatment from different caregivers. In the present study, BP-C1 was sent from the hospital to the local medical center, and a nurse gave the patients the injections either in the clinic or in the patient's home. It is uncertain if these pretreated MBC patients could have completed systemic chemotherapy far from their home, and it would, in all circumstances, have been costly for them.

In the subset analysis, we found that the sum of target lesions increased significantly in $\mathrm{ER}+$ and $\mathrm{PtR}+$ patients in spite of BP-C1 treatment, whereas the sum of target lesions decreased, however, insignificantly, in hormone receptor-negative patients. These findings correlate with the established effects of the receptors, although it is somewhat surprising that HER2 expression did not influence the effects of BP-C1. Perhaps this finding reflects that hormone receptor-positive and hormone receptor-negative tumors in HER2-positive breast cancer show distinct histopathological features that may be relevant to their clinical behaviour. ${ }^{34}$ TNBC comprised many different disease entities ${ }^{8}$ and accounts for $10 \%-20 \%$ of all cases. Convenient treatments used for MBC that target these receptors are not effective for TNBC, and chemotherapy is still the primary systemic treatment for 
TNBC patients in both the early and metastatic stages of the disease. However, the outcome is, overall, poor in triplenegative $\mathrm{MBC}$ and novel treatment strategies are highly desirable. So far, anthracyclins, taxanes, and carboplatin as single agents or in combination with other treatments are frequently used, but toxicity that necessitates delays dose reduction or ending the treatment is a common side effect. In the present study, we observed that the efficacy of BP-C1 treatment increased with the number of negative receptors. Only four mild-to-moderate AEs were considered as related to BP-C1 treatment, and the QOL was maintained during the treatment.

\section{Conclusion}

BP-C1, due to its efficacy, very few side effects, maintaining the QOL and patient-friendly and cost-effective way of administration, may be an important novel compound for the treatment of MBC and, in particular, the triple-negative subgroup of these patients. The next steps should be studies of BP-C1 monotherapy continued until disease progression; refinement of receptor results in a larger patient sample and analyses of the outcome of combination treatment of BP-C1 with other anticancer drugs.

\section{Disclosure}

The authors report no conflicts of interest in this work.

\section{References}

1. Autier P, Boniol M, La Vecchia C, Vatten L, Gavin A, Héry C, Heanue M. Disparities in breast cancer mortality trends between 30 European countries: retrospective trend analysis of WHO mortality database. BMJ. 2010;341:c3620.

2. Berry DA, Cronin KA, Plevritis SK, et al; Cancer Intervention and Surveillance Modeling Network (CISNET) Collaborators. Effect of screening and adjuvant therapy on mortality from breast cancer. $\mathrm{NEngl}$ J Med. 2005;353(17):1784-1792.

3. Cardoso F, Spence D, Mertz S, et al. Global analysis of advanced/ metastatic breast cancer: decade report (2005-2015). Breast. 2018;39:131-138.

4. Howlader N, Noone AM, Krapcho M, et al., editors [homepage on the Internet]. SEER Cancer Statistics Review, 1975-2013. Bethesda, MD: National Cancer Institute; Available from: http://seer.cancer.gov/ csr/1975_2013/, based on November 2015 SEER data submission, posted to SEER web site, April 2016.

5. Ufen MP, Köhne CH, Wischneswky M, et al. Metastatic breast cancer: are we treating the same patients as in the past? Ann Oncol. 2014;25(1):95-100.

6. Partridge AH, Rumble RB, Carey LA, et al. Chemotherapy and targeted therapy for women with human epidermal growth factor receptor 2-negative (or unknown) advanced breast cancer: American Society of Clinical Oncology Clinical Practice Guideline. J Clin Oncol. 2014;32(29):3307-3329.

7. Al-Mahmood S, Sapiezynski J, Garbuzenko OB, Minko T. Metastatic and triple-negative breast cancer: challenges and treatment options. Drug Deliv Transl Res. 2018;8(5):1483-1507.
8. Bianchini G, Balko JM, Mayer IA, Sanders ME, Gianni L. Triplenegative breast cancer: challenges and opportunities of a heterogeneous disease. Nat Rev Clin Oncol. 2016;13(11):674-690.

9. Early Breast Cancer Trialists' Collaborative Group (EBCTCG), Peto R, Davies C, et al. Comparisons between different polychemotherapy regimens for early breast cancer: meta-analyses of long-term outcome among 100,000 women in 123 randomised trials. Lancet. 2012;379(9814):432-444.

10. Cortazar P, Zhang L, Untch M, et al. Pathological complete response and long-term clinical benefit in breast cancer: the CTNeoBC pooled analysis. Lancet. 2014;384(9938):164-172.

11. Carey LA, Dees EC, Sawyer L, et al. The triple negative paradox: primary tumor chemosensitivity of breast cancer subtypes. Clin Cancer Res. 2007;13(8):2329-2334.

12. Decatris MP, Sundar S, O’Byrne KJ. Platinum-based chemotherapy in metastatic breast cancer: current status. Cancer Treat Rev. 2004;30(1):53-81.

13. Wang X, Wang X, Guo Z. Functionalization of platinum complexes for biomedical applications. Acc Chem Res. 2015;48(9):2622-2631.

14. Dewi S, Larsen S, Srimuninnimit V, et al. Benzene-poly-carboxylic acid complex with cis-diammineplatinum (II) dichloride in the treatment of stage IV breast cancer patients. Open Breast Cancer J. 2013;5:7-15.

15. Fares F, Azzam N, Fares B, Larsen S, Lindkaer-Jensen S. Benzene-polycarboxylic acid complex, a novel anti-cancer agent induces apoptosis in human breast cancer cells. PLoS One. 2014;9(2):e85156.

16. Larsen S, Butthongkomvong K, Manikhas A, et al. BP-C1 in the treatment of patients with stage IV breast cancer: a randomized, doubleblind, placebo-controlled multicenter study and an additional open-label treatment phase. Breast Cancer (Dove Med Press). 2014;6:179-189.

17. Carlsen KH, Kramer J, Fagertun HE, Larsen S. Loratadine and terfenadine in perennial allergic rhinitis. Treatment of nonresponders to the one drug with the other drug. Allergy. 1993;48(6):431-436.

18. Pocock SJ. Clinical Trial; A Practical Approach. Hoboken (NJ): John Wiley \& Sons; 1989.

19. Razali N, Wah YB. Power comparisons of Shapiro-Wilk, KolmogorovSmirnov, Lilliefors and Anderson-Darling tests. J Stat Model Anal. 2011;2(1):21-33.

20. Thomopoulos NT. Statistical Distributions; Applications and Parametric Estimation. 4th ed. Cham, Switzerland: Springer International Publishing; 2017.

21. Schott JR. Matrix Analysis for Statistics. Hoboken (NJ): John Wiley \& Sons; 2017.

22. Altman DG. Practical Statistic for Medical Research. 1st ed. London: Chapman \& Hall; 1991.

23. Agresti A. Categorical Data Analysis. 2nd ed. Hoboken (NJ): John Wiley \& Sons; 2002.

24. National Research Council. The Prevention and Treatment of Missing Data in Clinical Trials. Washington(DC): National Academy Press; 2010:110-112.

25. Shao J, Zhaonh B. Last observation carry-forward and last observation analysis. Stat Med. 2013;22(15):2429-2441.

26. Tabachnick BG, Fidell LS. Using Multivariate Statistics. 5th ed. Boston: Pearson Education, Inc; 2007.

27. Eisenhauer EA, Therasse P, Bogaerts J, et al. New response evaluation criteria in solid tumours: revised RECIST guideline (version 1.1). Eur J Cancer. 2009;45(2):228-247.

28. Rosenberg B, Vancamp L, Trosko JE, Mansour VH. Platinum compounds: a new class of potent antitumour agents. Nature. 1969;222(5191):385-386.

29. Rozencweig M, Nicaise C, Beer M, et al. Phase I study of carboplatin given on a five-day intravenous schedule. J Clin Oncol. 1983;1(10):621-626.

30. Galluzzi L, Marsili S, Vitale I, et al. Vitamin B6 metabolism influences the intracellular accumulation of cisplatin. Cell Cycle. 2013;12(3):417-421.

31. Marrache S, Pathak RK, Dhar S. Detouring of cisplatin to access mitochondrial genome for overcoming resistance. Proc Natl Acad Sci US A. 2014;111(29):10444-10449.

32. Anisimov VN, Larsen S, Lofberg S, Baldueva IA at al. Results and prospects of development of new polyphenolic drugs for cancer patients. Oncotarget. 2017;8(59): 100951-100956 
33. Kristiansen VM, Dewi S, Horsberg TE, et al. Tolerability and pharmacokinetic profile of a novel benzene-poly-carboxylic acids complex with cis-diammineplatinum (II) dichloride in dogs with malignant mammary tumours. Vet Comp Oncol. 2017;15(1):118-132.

34. Corbett T, Valeriote F, Lorusso P, et al. In vivo methods for screening and preclinical testing: use of rodents solid tumors for drug discovery. In: Teicher BA, editor. Anticancer Drug Development Guide: Preclinical Screening, Clinical Trials, and Approval. New York: Springer; 2013:75-101.
35. Guldberg P, Fang JF, Kirkin A, Dzhandzhougazian K. Immunological Study of BP-Cl and the Related Compounds. Cancer Genomic Laboratory. Copenhagen: Institute of Cancer Biology, Danish Cancer Society; 2011.

36. Lindkær-Jensen S, Larsen S, Habib-Lindkær-Jensen N, Fagertun HE. Positive effects on hematological and biochemical imbalances in patients with metastatic breast cancer stage IV, of BP-C1, a new anticancer substance. Drug Des Devel Ther. 2015;9:1481-1490.
Breast Cancer - Targets and Therapy

\section{Publish your work in this journal}

Breast Cancer - Targets and Therapy is an international, peerreviewed open access journal focusing on breast cancer research, identification of therapeutic targets and the optimal use of preventative and integrated treatment interventions to achieve improved outcomes, enhanced survival and quality of life for the cancer patient

\section{Dovepress}

The manuscript management system is completely online and includes a very quick and fair peer-review system, which is all easy to use. Visit http://www.dovepress.com/testimonials.php to read real quotes from published authors. 